\title{
Laboratoire Déberlinisation: Art, Finance, and the Legacies of Colonialism in Contemporary African Art: an Interview with Mansour Ciss Kanakassy
}

\author{
Conor McGarrigle \\ Technological University Dublin, conor.mcgarrigle@tudublin.ie \\ Marisa Lerer \\ Manhattan College
}

Follow this and additional works at: https://arrow.tudublin.ie/aaschadpart

Part of the Art Practice Commons, Contemporary Art Commons, Fine Arts Commons, Interactive Arts Commons, Interdisciplinary Arts and Media Commons, Painting Commons, Printmaking Commons, and the Sculpture Commons

\section{Recommended Citation}

Marisa Lerer \& Conor McGarrigl. e (2018). Laboratoire Déberlinisation - Art, Finance, and the legacies of colonialism in contemporary african art: an Interview with Mansour Ciss Kanakassy. Visual Resources, 34:1-2, 135-142. DOI: 10.1080/01973762.2018.1451967

This Article is brought to you for free and open access by the Fine Arts at ARROW@TU Dublin. It has been accepted for inclusion in Articles by an authorized administrator of ARROW@TU Dublin. For more information, please contact arrow.admin@tudublin.ie, aisling.coyne@tudublin.ie,gerard.connolly@tudublin.ie.

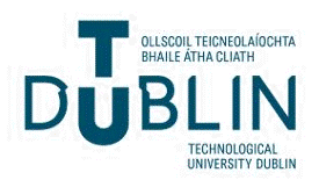




\title{
Laboratoire Déberlinisation - Art, Finance, and the Legacies of Colonialism in Contemporary African Art: An Interview with Mansour Ciss Kanakassy
}

\author{
Marisa Lerer \& Conor McGarrigle
}

Preprint Version to cite this article: Marisa Lerer \& Conor McGarrigle (2018) Laboratoire Déberlinisation - Art, Finance, and the Legacies of Colonialism in Contemporary African Art: An Interview with Mansour Ciss Kanakassy, Visual Resources, 34:1-2, 135-142, DOI:

10.1080/01973762.2018.1451967 


\title{
Laboratoire Déberlinisation - Art, Finance, and the Legacies of Colonialism in Contemporary African Art: An Interview with Mansour Ciss Kanakassy
}

\author{
Marisa Lerer and Conor McGarrigle
}

\begin{abstract}
Mansour Ciss Kanakassy (b. 1957) is a Berlin-based Senegalese artist whose practice addresses the legacy of colonialism in contemporary Africa, in particular as it is expressed in the financial systems of the former Francophone colonies of West Africa, where the currency, the CFA franc, historically tied to the French franc, is now pegged to the euro. The acronym CFA originally stood for Colonies Françaises d'Afrique - French Colonies of Africa - and now Communauté Financière Africaine - African Financial Community. In 2001, Ciss Kanakassy created the Laboratoire Déberlinisation (Déberlinisation Laboratory), a multifaceted project that traces contemporary African issues to the Berlin Conference of 1884-1885, which divided Africa among the great powers of Europe. The project, which includes the creation and circulation of a pan-African currency, the AFRO, and an international travel document, the Global Pass, has been extensively exhibited throughout Africa and Europe, and in China. In this interview, we discuss the origins of the Laboratoire Déberlinisation and the role of the AFRO in understanding the financial entanglements of neocolonialism.
\end{abstract}

Keywords: Laboratoire Déberlinisation; Mansour Ciss Kanakassy (b. 1957); the AFRO; Alternative Currency; Pan-Africanism; Baruch Gottlieb (b. 1966); Dak'Art Biennial

Your Déberlinisation project, in collaboration with Baruch Gottlieb (b. 1966), refers to the Berlin Conference of 1884-1885, which divided Africa into spheres of European colonial influence. These spheres of influence became, in many cases, the de facto borders of independent Africa in the 1960s. It is almost 60 years since Senegal achieved its political independence, but this project suggests that the geopolitical repercussions are still felt in Africa today and that there still is a need for a Déberlinisation. Could you discuss the ways that the colonial past is manifested today and why you created this art project to undo its effects?

I would say that Déberlinisation Laboratory is my obsession. In the history of the African continent it is the partition of Africa by the great powers, more than any other event, that has stripped us of our resources, our culture and customs, our wealth, our achievements, and our capacity for solidarity. That is why as Africans our main concern should be to define a new strategy to combat the denigration of 
our continent, while acknowledging our bitterness, indignation, and frustration. This is the central mission of the Laboratory; its role is to create symbolic encounters that allow African artists to research and actively rethink the history of the continent and, in so doing, to facilitate an understanding of African contemporary art and its direct relationship to Africa's future. In short, the Déberlinisation Laboratory is a free space that aims to help artists and intellectuals from Africa and the diaspora reflect on cultural projects and concepts that represent completely new territory.

Created in 2001 in the belly of the beast, the Déberlinisation Laboratory is a historical and cultural concept that draws its inspiration from the Berlin Conference of 1884-1885 that decided the arbitrary borders of Africa, without the agreement and support of the African people, and still enables the legitimization and expansion of the original colonial conquests by neocolonial political domination and exploitation by foreign multinationals. In particular, it is concerned with the financial domination of the CFA, the currency of the [former] French Colonies of Africa. The Déberlinisation Laboratory is a center of artistic experimentation, an organization involved in a search for solutions to issues that jeopardize the development of African societies. It is a group of artists committed to finding solutions to the ills that beset our society through action and through international exchanges between young people, artists, and intellectuals who are responsible for managing the positive and negative changes on our planet. It seeks to establish a new art diplomacy where politicians have failed, with the aim of proposing solutions and providing clear answers. The laboratory functions as a multifaceted space in which utopian and concrete engagements happen in the spirit of a radical transformation of the status quo. It acts as a melting pot of reflections on the past and present of Africa, with the aim of leading to endogenous and sustainable development for the continent, a place where art and ideas can lead to a restoration of the collective memory and dignity of the continent.

Recent discussions of artistic-political approaches have revitalized the dream of a political art practice, drawing distinctions between an established political order and a non-established one, that refer to, on the one hand, political art and, on the other, a pre-existing state of the political (an art of politics). Instead of asking how art can drive political momentum for empowerment, we want to raise the question of how art can help renegotiate the establishment of an ideological order as a symbolic and economic order in the first place, so that we open a channel of political debates, which establish a utopian counter-narrative to the status quo. While literary discourse shows that art can have agency in this regard, in today's discussion of the status of political art, art is still thought of in various forms as a catalyst. We would like to shift the focus away from a notion of redemption and think more practically. Rather than asking how art can engage as a form of protest, we would rather look at how art can articulate political questions and ideally formulate a counter-narrative. We are interested in how an existing discourse of power translates into praxis and how an emancipated art can illuminate ideological claims on political discourse.

It is important for me to share the history of the Laboratory. On November 14, 1884 the great conference called the Congo Conference was organized, in the presence 
of the German Chancellor Otto Von Bismarck (in office 1871-1890) and with the participation of the German government. Fifteen European countries were represented, in addition to the United States. As its name suggests, the Déberlinisation Laboratory refers to this famous conference, which sanctioned the violent partition of Africa by European powers to create the borders that today still structure and distort Africa. The Berlin Conference is the historical reference point of the Déberlinisation Laboratory project, which is inspired by the legendary performance-theater group Laboratoire Agit-Art (founded in Dakar, Senegal in 1974) and my friends in Berlin, the artists Baruch Gottlieb and Christian Hanussek (b. 1953), with whom I collaborated on the design of the AFRO banknotes when I had the idea of creating a single African currency to counter the CFA franc. The Déberlinisation Laboratory not only treats Africa as a victim of colonialism and neocolonialism, but also seeks to exorcise the ghosts of the past. I do not clearly separate art and political activism; nonetheless, I need to take a break to concentrate on art. Similarly, I cannot always be on the road; I also need to be at home, whether that is in Senegal, Germany, or China.

The AFRO asks an essential, necessary question [about the CFA] that every African citizen needs to reflect on, but the concept also has a utopian aspect because it represents the creative impulse, and I like that. Culturally speaking, part of Africa grew up in France. We francophone Africans are confronted today with a radical phenomenon of what we might call assimilation by currency. I do not like the CFA franc; I prefer the AFRO.

The AFRO is a speculative pan-African currency with its own banknotes, depicting pan-African intellectuals such as the political economist Dani Wadada Nabudere (1932-2011) and the leader of the pan-African movement Marcus Garvey

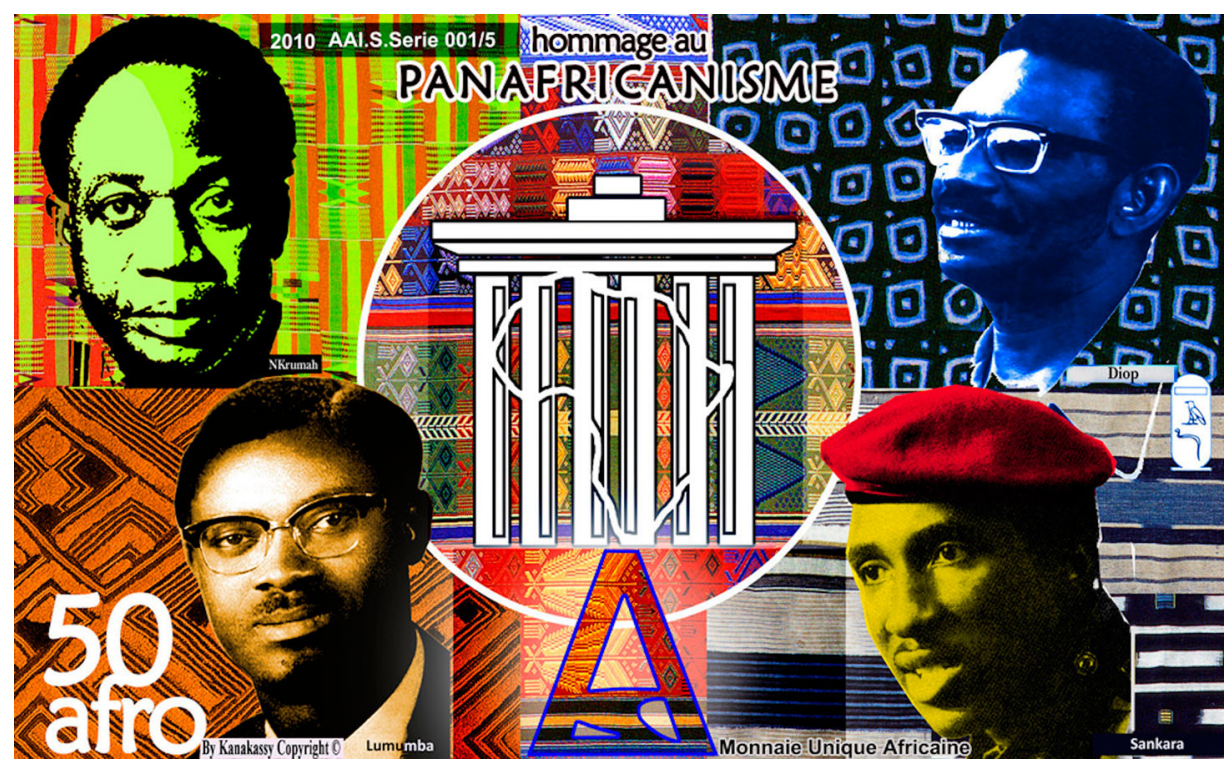

Figure 1. Mansour Ciss Kanakassy, United States of Africa (2010). Print on Dibond, 120 x $80 \mathrm{~cm}$. Image: Courtesy of the artist. 
(1887-1940). It has a fixed one-for-one exchange rate with the euro and can be exchanged for real currency. As a conceptual project it functions as a critique of capitalism and its colonial roots. Can you discuss how it works in practice as a mechanism for exchange? Is it primarily an artwork or does it function as an alternative currency such as the Bijlmer Euro in Amsterdam or the London local currency the Brixton Pound, which form local exchange networks, or is it a practical economic proposal for a pan-African currency?

In effect, the AFRO has become central to the Déberlinisation Laboratory; it is the new currency of African art. It is more than the counterpart of the euro or the dollar and even more so with the African currencies that have no future, especially the pseudoCFA franc. However, the AFRO is not a speculative currency! Because we are creating utopian and allegorical art, the preferred domain of free spirits. The AFRO is not always popular when first distributed. The first time we distributed the AFRO was in Dakar during the 2008 Dak'Art Biennial of Contemporary African Art in Senegal. On this occasion, when I gave it to President Abdoulaye Wade (in office 2000-2012) he seemed taken aback. In Belgium, for example, the authorities banned the public issuance of the Afro-Lumumba note, commemorating the fiftieth anniversary of the assassination of Patrice Lumumba (1925-1961). This is why I showed the Afro-Lumumba as a large format print mounted on Dibond, for an exhibition in the Palais des Beaux Art, Brussels. In Uganda, the Afro-Nabudere could not be put into circulation as a regional currency to finance the Marcus Garvey Pan-African University, as the [Yoweri] Museveni (assumed office 1986) government considered it an "illegal" political opposition project. In Senegal the Afro-Pixel circulates in the Sicap District of Dakar as a local

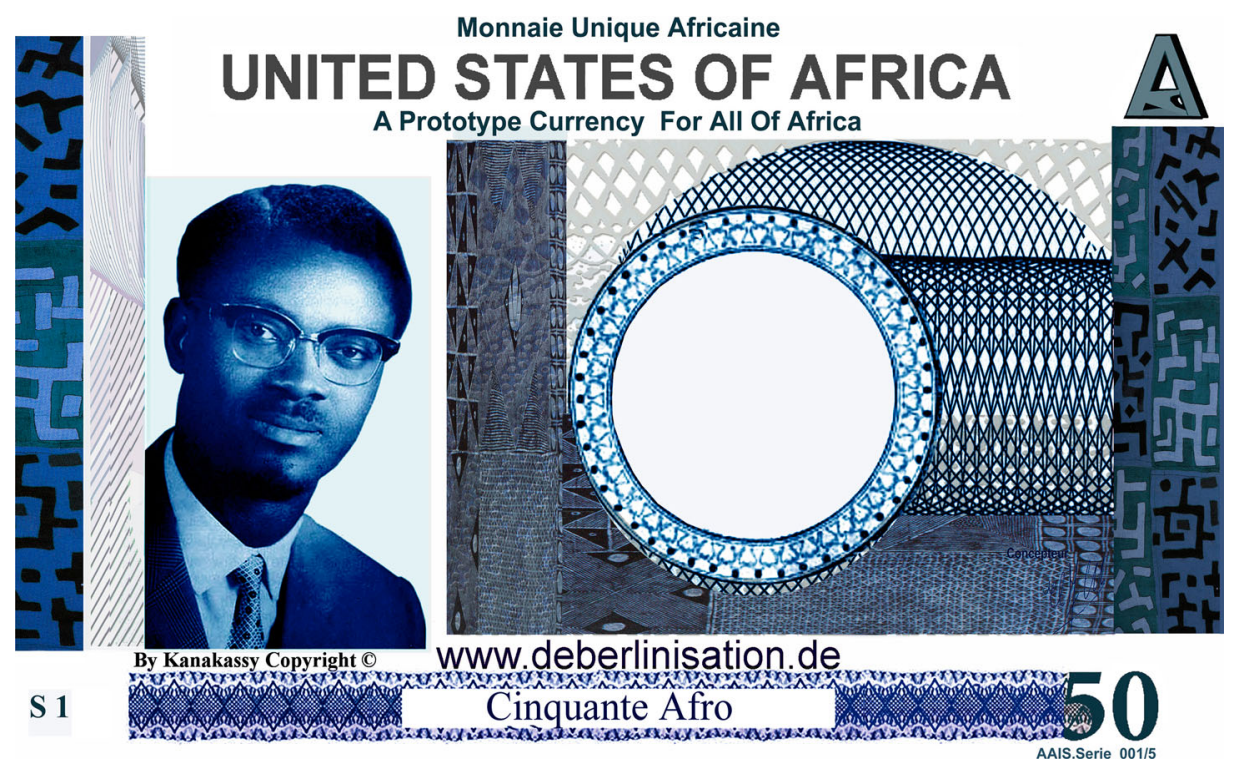

Figure 2. Mansour Ciss Kanakassy, Hommage au Panafricanisme (2010). Print on Dibond, 120 x $80 \mathrm{~cm}$. Image: Courtesy of the artist. 
currency distributed and exchanged at [the non-profit organization] Kër Thiossane as a local currency, a commons.

This demonstrates that the AFRO can become a force to be reckoned with and break the shackles of the colonial history of Africa's national fragmentation to build a united Africa from the base of the people. The CFA franc was introduced in 1945 with the ratification of the Bretton Woods accord in 15 French colonies. It is managed by the Central Bank of West African States (BCEAO), as the currency of the West African Economic and Monetary Union (UEMOA), with the countries of Benin, Burkina Faso, Ivory Coast, Guinea-Bissau, Mali, Niger, Togo, and Senegal. The CFA franc is linked to the euro at different fixed exchange rates and also to the Central African Central Bank (BEAC), which is the Central African Economic and Monetary Union consisting of Equatorial Guinea, Gabon, Cameroon, the Republic of Congo, Chad, and the Central African Republic.

This is a complex and evolving multi-part project that involves the AFRO currency, the Global Pass, the AFRO-Express card, ATMs, and a series of performative events and AFRO exchanges, could you discuss its scope and the interconnections between the parts?

The Global Pass is an identity card issued to all the inhabitants of the planet, allowing them to live and work wherever they want. It was created in Arnhem, Holland in 2008, then relaunched at Transmédiale 10 (Berlin, 2009), in an initial series of 1000 copies. Each one was personalized. It is a symbolic work, an individualized project that addresses the international community's right to mobility and movement for the citizens of the world. The big questions today are: How is it that Ivorian cocoa travels more easily than the Ivorian who picks it? Why are the regions richest in natural resources the poorest? Globalization benefits some and disadvantages the majority. Among the losers are Africans whose continent remains tied to borders drawn in Berlin more

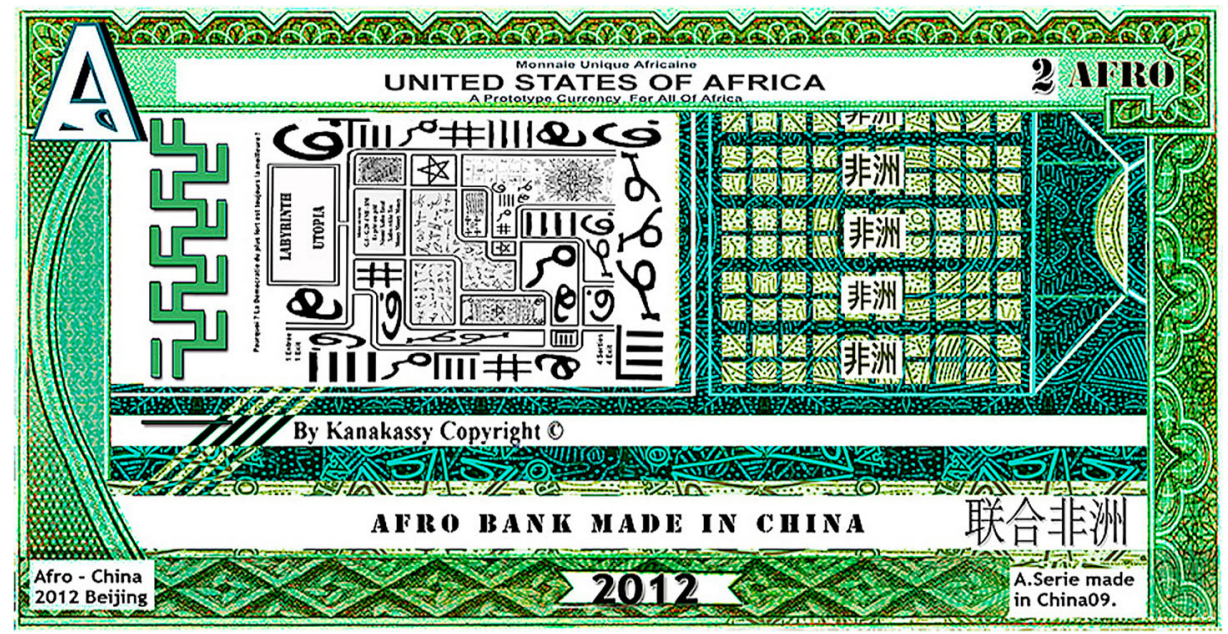

Figure 3. Mansour Ciss Kanakassy, Afro Made in China (2012). Print on 150g paper, 16.5 x 8 cm. Image: Courtesy of the artist. 
than 100 years ago. Although today's average African is part of the cultural networks of rampant globalization that characterize the twenty-first century, they have little access to the freedom of action or autonomy that this should bring, either economically or culturally. The borders imposed in the 1884-1885 Berlinization continue to hinder movement. They prevent the movement of Africans on their own continent, to say nothing of other continents, from which they are for the most part de facto excluded. Since 2001, the Déberlinisation Laboratory has been fighting against this state of affairs through the invention of the AFRO and the AFRO-Express Card, as well as via the $M$ $A F R O$ project. This is true also for this fourth project, which is closely linked to the previous ones: the Global Pass.

You have mentioned that you take on the role of a banker with this work. Are there tensions between the AFRO's function as an art object and socially engaged performative artwork, and the more practical economic aspects of a currency, which, while speculative, are very present in the work? Are you suggesting that artists need to be economists to affect change in the world? Are these tensions resolved in the work or is it necessary that they remain unresolved?

I cannot speak to the history of the currency while the project is still ongoing. We are not about making banknotes, but rather we are about making art and utopia. I am not thinking about the fundamentals of sovereign countries, which are capable of commissioning works of art to symbolize real possibilities, such as Pierre Goudiaby's (b. 1947) African Renaissance Monument, Dakar (installed 2010) that President Wade commissioned. This is not what I am doing with the AFRO. Because the artistic medium of the AFRO is economics, it represents a message of hope for Africans - a crystal ball lodged in the consciousness of the 15 leaders of the francophone African states. The

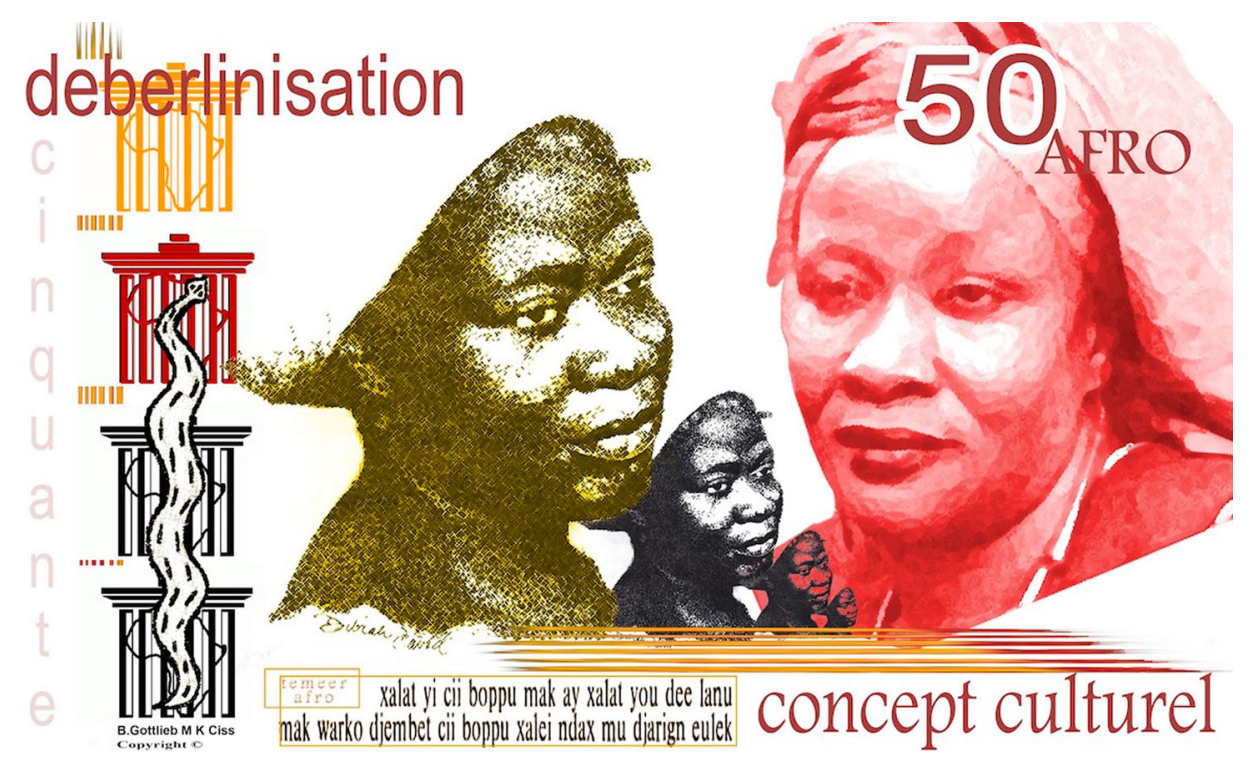

Figure 4. Mansour Ciss Kanakassy, Hommage à la femme Africaine (2006). Print on 150g paper, $15 \mathrm{x} 9 \mathrm{~cm}$. Image: Courtesy of the artist. 
CFA franc, this colonial and neocolonial currency, still printed in France, is too complex a problem to discuss in a few lines.

Alternative currencies are inherently utopian in nature. The AFRO in addition has strong conceptual connections with pan-Africanism, which itself is a utopian movement, albeit one based in Realpolitik. Are we correct in seeing this as a utopian project? Do you think utopianism's blending of geopolitics, economics, and culture can provide solutions in these times of crisis?

The AFRO acts as a healing phase for contemporary Africa. I mostly assume the role of a contemporary Marabout who seeks to exorcise a sick and traumatized society. ${ }^{1}$

When Senegal achieved independence in 1960, its first president, Léopold Sédar Senghor (in office 1960-1980) - who was a poet and cultural theorist and part of the Négritude movement - provided generous state patronage for the visual arts. What impact did arts patronage have on building the postcolonial Senegalese nation? Does this patronage resonate today?

Yes, Senegal has an exceptional cultural heritage thanks to Senghor, who, since independence in 1960, established a strong cultural policy relative to other African countries. The postcolonial Senegalese nation and its infrastructure was built by Senghor. It should also be remembered that these same infrastructures inherited from Senghor were destroyed in the 1980 s by international financial institutions such as the International Monetary Fund (IMF) and the World Bank. However, the most obvious answer after Senghor in terms of cultural heritage is the Dak'Art Biennial.

You live in Berlin, a center of the international art market, and are from Dakar. Can you discuss the place of this work in the art market and the differences between the Berlin art market and that of Dakar?

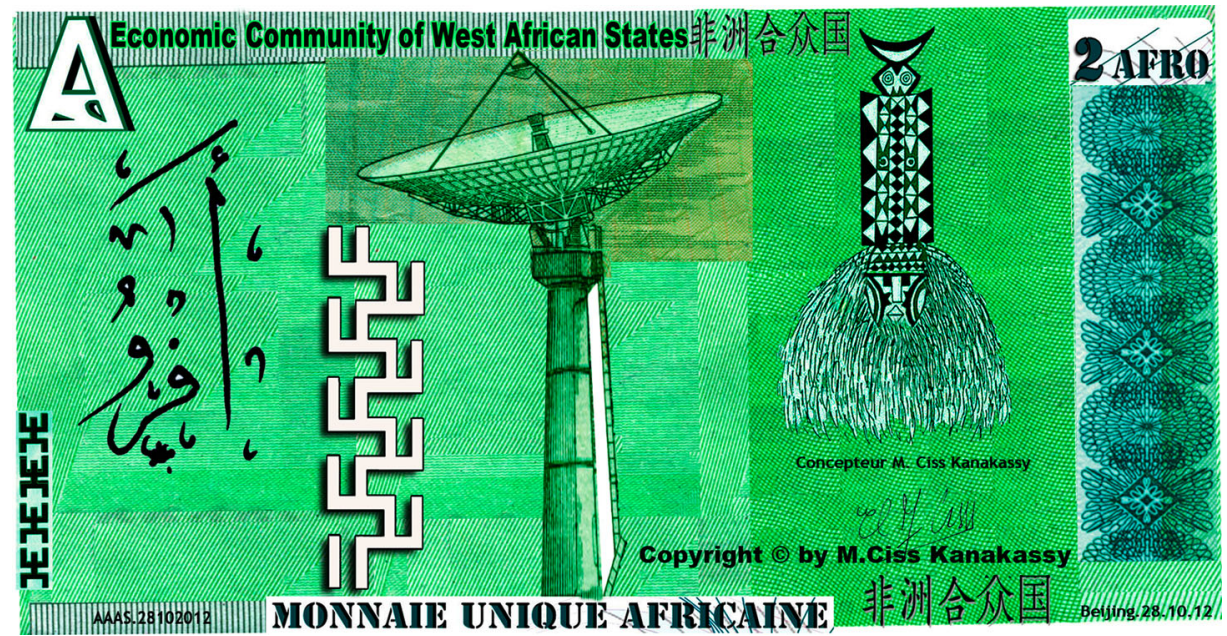

Figure 5. Mansour Ciss Kanakassy, Afro Made in China (2012). Print on 150g paper, 16.5 x 8 cm. Image: Courtesy of the artist. 
My work is well known in Africa, in Europe, and even in China, but I would say that my ideas operate outside of the context of the art market. The places where I show my work in Berlin are closely connected with those in Dakar.

\section{Disclosure statement}

No potential conflict of interest was reported by the authors.

MANSOUR CISS KANAKASSY is a Senegalese artist who has lived in Berlin since 1993. He is a visual artist, and describes himself as an activist, a pan-Africanist, a global citizen, a utopian, and a radical. Mansour's art is diverse and his work has always been politicized, dealing with issues of migration, integration, cultural diversity, mutual understanding, and mutual responsibility, and he shares the pan-African vision of a united Africa that can sustain itself into the future by confronting the legacy of colonialism. He has exhibited widely in Africa, Asia, and Europe, in group and solo shows at the Dakar Biennial, the National Museum of Mali, Bamako, the Neue Gesellschaft für Bildende Kunst, Berlin and the Museum der Weltkulturen, Frankfurt am Main, and the Palais des Beaux Arts, Brussels, among other venues. His works are in the collections of the Museum der Weltkulturen, Frankfurt am Main, the National Collection of Senegal, and the Central Bank of West African States. He is a recipient of the Leopold Sedar Senghor Award for artistic excellence. Inspired by black intellectuals like Senghor, Cesaire, and many others, and by pan-Africanist icons like Kwame Nkrumah and Thomas Sankara, his art invites reflection on imperialist policies adopted by the west towards Africa and expresses his vision for Africa and the world.

MARISA LERER and CONOR MCGARRIGLE, respectively from Manhattan College (New York) and Dublin Institute of Technology, are the Guest Editors of this Special Issue.

\section{Note}

1. A Marabout is a Muslim religious leader and teacher in West Africa. 